\title{
Comparison of a selective and a non-selective medium in the diagnosis of gonorrhoea to ascertain the sensitivity of Neisseria gonorrhoeae to vancomycin
}

\author{
A. REYN AND M. W. BENTZON \\ From the WHO International Reference Centre for Gonococci, Neisseria Department and Biostatistical \\ Department, Statens Seruminstiutt, Copenhagen, Denmark
}

The incorporation of inhibitory substances in media for primary isolation of Neisseria gonorrhoeae has developed gradually (Reyn, 1969; Stuart, Toshach, and Patsula, 1954; Thayer and Martin, 1964, 1966). The addition of vancomycin ( $3 \mu \mathrm{g} . / \mathrm{ml}$.), sodium colistimethate $(7.5 \mathrm{\mu g} . / \mathrm{ml}$.$) and nystatin (12.5$ i.u./ml.) was proposed by Thayer and Martin (1966). This combination (and other similar combinations) of antibiotics, now in common use, greatly facilitates the recognition of $N$. gonorrhoeae in highly contaminated specimens.

However, the existence of gonococcal strains which are very sensitive to the antibiotics hitherto used for the suppression of Gram-positive organisms is a serious drawback. One of us (Reyn, 1969) has estimated the frequency to be about 3 per cent. These strains could not grow on a medium containing $3 \mu \mathrm{g} . / \mathrm{ml}$. vancomycin and they were also very sensitive to penicillin, streptomycin, and tetracycline, but resistant to nystatin and polymyxin.

In Denmark, the proportion of gonococcal strains sensitive to penicillin has increased since 1967. This implies an increasing risk of losing more and more strains if a selective medium is used as the only one.

Vancomycin was therefore reduced to $2 \mu \mathrm{g} . / \mathrm{ml}$. in our selective medium, but was found to inhibit the Gram-positive flora almost as much as $3 \mu \mathrm{g} . / \mathrm{ml}$.

The aim of the present investigation of a large number of specimens was to estimate the incidence of strains sensitive to vancomycin at the $2 \mu \mathrm{g} . / \mathrm{ml}$. level.

\section{Material and methods}

\section{SPECIMENS}

From February 6 to November 19, 1969, 50,000 routine specim $2 n s$ of discharge (from 50,000 sites) were inoculated on selective and non-selective media. In order to obtain a comparatively high number of gonococcal cultures,

Received for publication March 16, 1972

This study was supported by grants from the World Health Organization specimens chosen from venereological wards and clinics were transported to the laboratory in a solid medium of the Stuart type (Reyn, Korner, and Bentzon, 1960; Ringertz, 1960), using one infected charcoal-impregnated swab for inoculation on both media. The selective medium was always inoculated first. Half of each plate was inoculated by means of the swab and further spreading was done with platinum loops (Reyn, 1965). One-quarter of the specimens came from males and three-quarters from females; 8,098 sites showed growth of gonococci on one or both media, corresponding to 5,500 cases of gonorrhoea $(2,500$ males and 3,000 females). The results were recorded as follows: Negative No growth of gonococci.

Overgrown Overgrowth with non-identified contaminating organisms, except in the case of Proteus, which was diagnosed by its spreading and typical odour.

Positive Growth of gonococci; note was taken even if only a few colonies were observed.

The bacteriological diagnosis of $N$. gonorrhoeae was based on the presence of typical, oxidase-positive colonies which contained Gram-negative cocci and diplococci, and which produced acid from glucose only.

\section{SELECTION OF MATERIAL}

Cases $^{\star}$ in which at least one positive result was obtained were included in the material if discrepant results were found from at least one site on the two media. The results were described as discrepant if growth of gonococci was obtained on one medium and no growth or overgrowth by contaminating bacteria on the other. Thus, cases in which cultures from one or more sites were overgrown on one of the media were not included in the material unless a discrepancy was observed from at least one other site.

Selected in this way, the material comprised 2,002 sites from 944 cases ( 265 males and 679 females). Only specimens derived from urethra, cervix, or rectum were used for comparison of the two media.

All cultures obtained on non-selective medium only were subcultured on selective medium, and those which were completely or partly inhibited were lyophilized with a view to later sensitivity determination to antibiotics.

^These were not individual 'cases' but actually 'sets of results' as the records showed that about 5 per cent. of them originated from cases diagnosed previously 
MEDIA

Selective medium The HYL medium used was as described by Møller and Reyn (1965), but with one modification, viz. haemoglobin was replaced by 6.7 per cent. defibrinated, heated horse blood. The following antibiotics were added: polymyxin sulphate B 25 i.u., nystatin 25 i.u., and vancomycin $2 \mu \mathrm{g} . / \mathrm{ml}$.

Non-selective medium The same medium without antibiotics.

Fermentation medium Solid agar medium with 1 per cent. glucose or maltose (Juhlin, 1963).

Transport medium Stuart's formula, but with a higher agar concentration (Reyn and others, 1960; Ringertz, 1960), charcoal-impregnated swabs (Stuart and others, 1954).

\section{SENSITIVITY DETERMINATIONS}

These were to penicillin, streptomycin, tetracycline, vancomycin, polymyxin $B$, and nystatin. In all cases a plate dilution method (Reyn, Bentzon, and Ericsson, 1963) was used, but for vancomycin and polymyxin a diffusion method (Thomsen, 1962) was also used. The results were recorded as 50 per cent. inhibitory values $\left(\mathrm{IC}_{50}\right)$ (Reyn and others, 1963).

\section{Results}

GROWTH OF GONOCOCCI

The results obtained in 944 cases (2,002 sites) are presented in Table I. It is evident that the incidence of positive results per site is higher on the selective than on the non-selective medium.

\section{Males}

The incidence of positive results on the selective medium was of the same order of magnitude from the urethra and rectum. On the non-selective medium only 3 per cent. positive results were found from the rectum, whereas 41 per cent. were positive from the urethra. On the non-selective medium, 27 and 50 per cent. of the cultures from the urethra and rectum respectively were overgrown.

Females

The incidence of postive results was highest from the cervix ( 74 per cent. on selective and 56 per cent. on non-selective medium) and lowest from the rectum (60 and 5 per cent.). Many cultures from the urethra and especially from the rectum were overgrown on the non-selective medium (23 and 50 per cent. respectively.

Overgrown cultures were also found on the selective medium, but in small numbers, the highest value abserved being 8 per cent. in rectal specimens from males.

An analysis of the degree of growth of gonococci on the two media showed that 'few colonies' were recorded more frequently on selective medium than on non-selective medium, but that no correlation was observed between the observation of 'few colonies' on the two media. This might indicate that some of the positive results were lost on the non-selective medium, since that medium was always inoculated second.

Another observation was that, using the selective medium, 'few colonies' were observed less frequently in men than in women (both urethra and rectum), whereas no difference was observed on the nonselective medium (urethra). However, the total material of specimens showing 'few colonies' only was relatively small (4 per cent of the 2,002 sites).

TABLE I Survey of results obtained by simultaneous culture on selective and non-selective medium from 265 males and 679 females in whom discrepant results were obtained on the two media (total 2,002 sites)

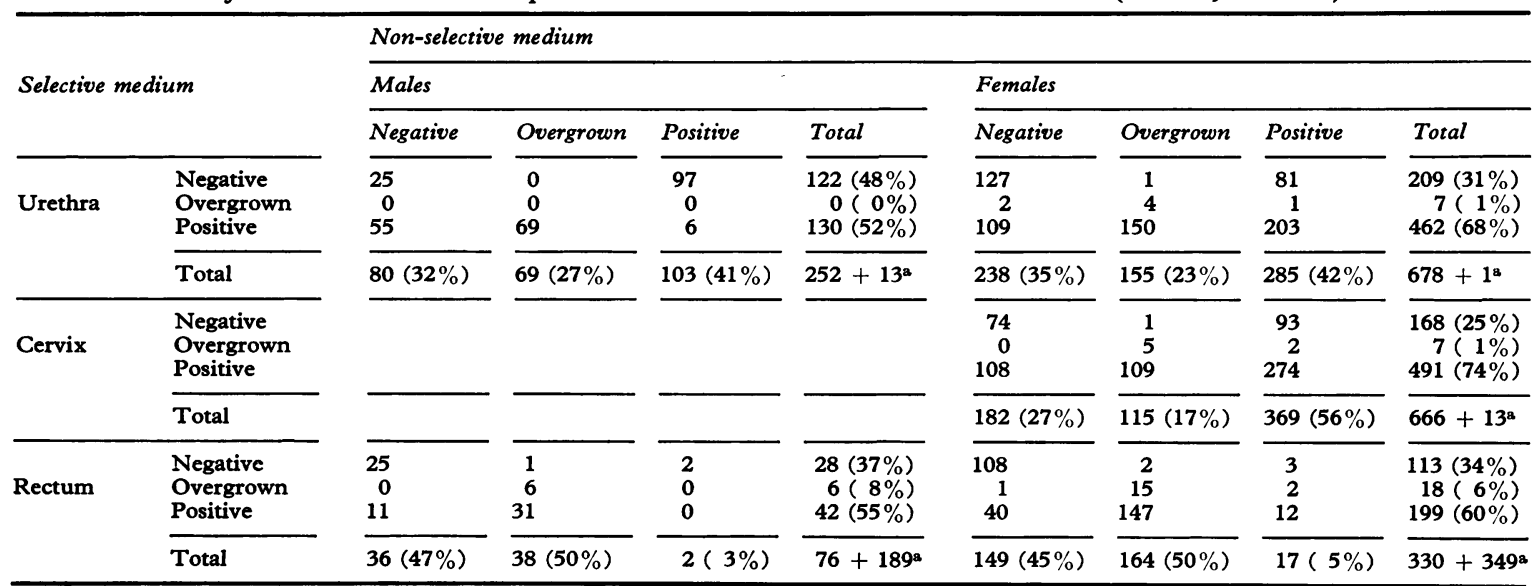

Not received 
The number of cases of gonorrhoea diagnosed on either selective (Group A) or non-selective medium (Group B) alone are compared in Table II (below). The findings from the urethra and rectum only are considered as well as those obtained using all the results available from the urethra, rectum, and cervix.

Altogether 204 cases (98 males and 106 females) were diagnosed on the non-selective medium only and 354 cases (161 males and 193 females) on the selective medium only. Thus, on the average, $1 \cdot 7$ times as many cases were diagnosed on the selective medium alone as on the non-selective medium alone.

Table II shows that the ratio $(\mathrm{A} / \mathrm{B})$ between the number of cases found by means of the selective medium alone and that found by means of the nonselective medium varies between 1.4 (results from urethral tests in males) and 12 (results from rectal tests in males). Thus, when selective and non-selective media are compared, it is important to specify the kind of material used for the comparison. This is further illustrated in Table III in which the results are shown for sites found positive on selective medium (Group A) and non-selective medium
(Group B) only. In this case, the ratios A/B vary much more than those shown in Table II. The highest values are seen in specimens from the rectum (males and females) and the lowest in specimens from the male urethra.

The relatively poor results obtained from the urethra in females on non-selective medium (A/B : $5 \cdot 4$, Table II) are compensated for when specimens from the cervix are included in the examination (A/B: 1 8). The percentage of female cases of gonorrhoea diagnosed on selective medium alone was $6 \cdot 4$ $(193 / 3,000)$ against $3.5(106 / 3,000)$ diagnosed on non-selective medium alone, viz. a 'gain' of 2.9 per cent. on the selective medium.

The corresponding percentages for males were $6 \cdot 4(161 / 2,500)$ and $3.9(98 / 2,500)$, with a 'gain' on the selective medium of 2.5 per cent.

The contaminating bacteria were not identified, except in the case of Proteus, since it is known that this is often to be found at all sites if observed in one site. This was also the case in the present material.

The incidence of Proteus among the total number of overgrown cultures was greater on the selective medium than on the non-selective medium. This was

TABLE II Cases of gonorrhoea diagnosed on either selective or non-selective medium alone

\begin{tabular}{|c|c|c|c|c|c|}
\hline \multicolumn{3}{|c|}{ Group } & $\begin{array}{l}A^{\mathrm{a}} \\
110 \\
188\end{array}$ & $\begin{array}{l}B^{\mathrm{b}} \\
79 \\
35\end{array}$ & $\begin{array}{l}\text { Ratio } A / B \\
1 \cdot 4 \\
5 \cdot 4\end{array}$ \\
\hline & Urethra and rectum & $\begin{array}{l}\text { Males } \\
\text { Females }\end{array}$ & $\begin{array}{r}39 \\
114\end{array}$ & $\begin{array}{l}18 \\
45\end{array}$ & $\begin{array}{l}2 \cdot 2 \\
2 \cdot 5\end{array}$ \\
\hline \multicolumn{2}{|c|}{$\begin{array}{l}\text { Total cases with all results available from urethra, rectum, } \\
\text { and cervix }\end{array}$} & Total & 354 & 204 & $1 \cdot 7$ \\
\hline
\end{tabular}

aPositive on selective medium only

bositive on non-selective medium only

TABLE II Sites positive on either selective or non-selective medium alone

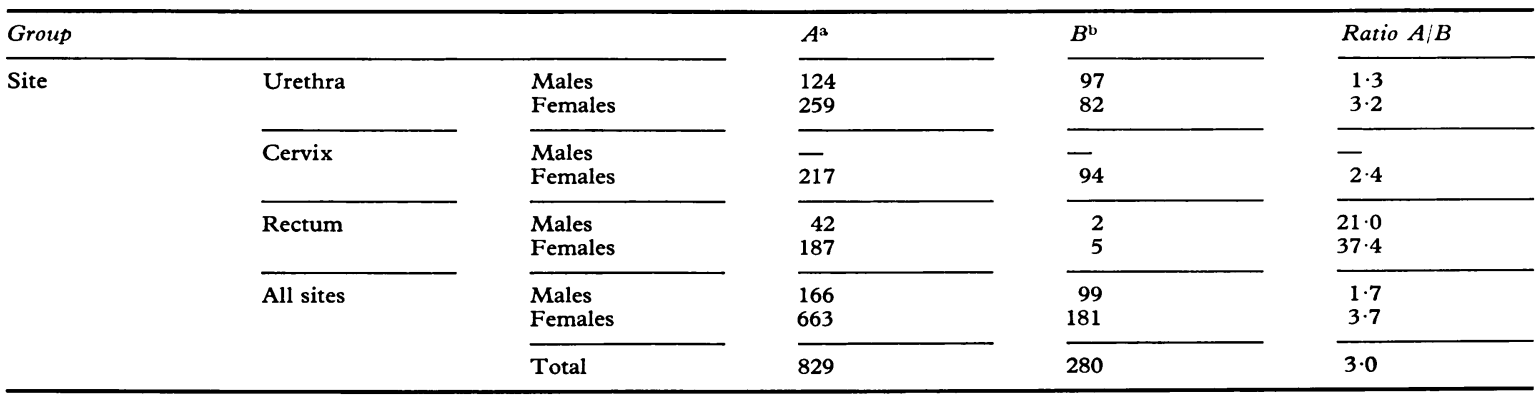

aPositive on selective medium only

bPositive on non-selective medium only 
to be expected, since the majority of the other contaminating bacteria were inhibited on the selective medium. Apparently, some inhibition of Proteus was also obtained on the selective medium in specimens from the urethra (males and females) and cervix, but this was not the case in specimens from the rectum (males and females). This indicates that classification of all these cultures as being overgrown by Proteus was, in fact, not correct. One would expect 'true' growth of Proteus to be more frequent in specimens from the rectum than from the other sites.

\section{SENSITIVITY DETERMINATIONS}

There was no primary growth on the selective medium in 204 cases, but in 84 of these there was full growth when they were subcultured on the same medium using a rather heavy inoculum.

The 'delicate' strains, which on repeated testing did not grow or grew less well on the selective medium, were tested against vancomycin (plate dilution method) and against polymyxin (diffusion method). Altogether, 131 strains of this kind were isolated, but six were lost on subculture, leaving 125 delicate strains from 120 cases for the sensitivity testing.

\section{Vancomycin}

The $\mathrm{IC}_{50}$ was $\leqslant 2 \mu \mathrm{g} . / \mathrm{ml}$. in 105 cultures, between 2.4 and $4.8 \mu \mathrm{g} . / \mathrm{ml}$. in fourteen; and about $16 \mu \mathrm{g} . / \mathrm{ml}$. in the remaining six. In 224 random gonococcal strains sent in with a request for sensitivity determination, the range of $\mathrm{IC}_{50}$ values was estimated as being from 2 to $80 \mu \mathrm{g} . / \mathrm{ml}$. by the diffusion method. The majority of these strains had $\mathrm{IC}_{50}$ values at $8 \mu \mathrm{g} . / \mathrm{ml}$.

\section{Polymyxin}

The IC $_{50}$ values were estimated by means of the diffusion method. The zone diameters observed corresponded to a range of $\mathrm{IC}_{50}$ values from 50 to $\geqslant 1,300 \mathrm{i} . \mathrm{u} . / \mathrm{ml}$. in both the delicate strains and in those chosen at random.

Growth of single colonies or sparse growth was often noticed within the inhibition zones in the case of both vancomycin and polymyxin. In the plate dilution experiments with vancomycin, partial inhibition was often seen over a wide range of dilutions, thus indicating varying degrees of sensitivity of the organisms within a given strain.

\section{Penicillin, streptonycin, and tetracycline}

The delicate strains and those chosen at random were also tested against penicillin, streptomycin, and tetracycline. The delicate strains were sensitive to all three drugs, whereas 37 per cent. of the other strains were less sensitive to penicillin ( 55 per cent. of these being resistant to streptomycin) and 8 per cent. were less sensitive to tetracycline. By plotting the results for the individual strains against each other, it was found that both the vancomycin and polymyxin values were correlated with the penicillin values. The correlations were weak and could be detected only when strains representing a wide range of $\mathrm{IC}_{50}$ values for penicillin were employed. A weak positive correlation was also observed between the polymyxin and vancomycin values.

The possibility of a synergistic effect of polymyxin was tested in 117 of the delicate strains as follows:

Four media were inoculated in the same way as that used in the plate dilution method for sensitivity determination, and the degrees of growth were recorded:

(1) Selective medium with nystatin, vancomycin, and polymyxin

(2) Same medium with nystatin only

(3) Same medium with vancomycin and nystatin

(4) Same medium with polymyxin and nystatin

Full growth was obtained by all strains on Media 2 and 4, but 103 strains were either completely or partly inhibited to the same degree on the two media which contained vancomycin with and without polymyxin (1 and 3 ). Ten of the remaining fourteen strains grew better on Medium 3 than on Medium 1, whereas the opposite effect was seen in four strains only. Thus, it was just possible to detect a weak inhibitory effect of polymyxin.

\section{Discussion}

In a series of strains from 1969, the incidence of delicate gonococcal strains which on primary inoculation were unable to grow on a selective medium containing vancomycin $(2 \mu \mathrm{g} . / \mathrm{ml}$.), polymyxin sulphate $B(25$ i.u. $/ \mathrm{ml}$.), and nystatin ( $25 \mathrm{i} . \mathrm{u} . / \mathrm{ml}$.) was estimated at 3.7 per cent. (204 of a total of 5,500 cases). This is considered to be a minimum estimate, because in the present investigation non-selective medium was always inoculated second, thus involving the risk of 'using up' the gonococci on the selective medium. However, in the present series, there was growth of 'few colonies' in only 4 per cent. of the sites. After subculturing, gonococci were able to grow on the selective medium in about 40 per cent. of cases when a heavy inoculum was used. Random variation in the original inocula and a 'training' effect during culture may account for this. In the remaining cases, sensitivity to vancomycin was the main cause of lack of growth on the selective medium.

Out of a total of 5,500 cases with gonorrhoea, 354 ( 6.4 per cent.) were diagnosed by means of the selective medium only. Thus, in this selected series with discrepant results on the two media, 1.7 times as many cases were diagnosed on the selective medium alone as on the non-selective medium alone. 
The advantage of the selective medium over the non-selective varied with the site and number of sites examined; the more sites examined the smaller the advantage of the selective medium. The search for gonococcal colonies was highly facilitated on the selective medium thus making a thorough spreading of the material of less importance.

As pointed out previously by several authors, the seleciive medium was especially superior in rectal specimens (Heimans, 1966; Roepstorff and Hammerström, 1966; Wilkinson, 1965). A large-scale comparison between a selective medium of the ThayerMartin type and a non-selective medium was carried out by Gästrin and Kallings (1968). The various sites were not specified, but on the average 2.6 times as many sites were positive on the selective medium alone as on the non-selective medium alone. This is in agreement with the present results in which 3 times as many sites were positive on the selective medium alone as on the non-selective medium alone Table III).

It is very likely that the great majority of the cases in males diagnosed on the non-selective medium only would have been recognized (and treated) by clinical symptoms and typical microscopy, but symptomless carriers would have remained undiagnosed. It is also likely that more than half of the cases in females found by means of the non-selective medium only would have remained undiagnosed and would thus have been left with the risk of developing complications and bacteraemia, especially during pregnancy and in connection with menstruation (Holmes, Counts, and Beaty, 1971). They would also have remained as sources of infection.

The ideal is to use a selective and a non-selective medium together. If this is not done, there is a risk of losing the strains sensitive to vancomycin.

Since November, 1969, it has not been technically possible to use two media in more than one-third of the specimens received for diagnosis. The probable selective effect of this was checked in 530 random cases of gonorrhoea diagnosed in October, 1971. Uniform results were obtained in 452 cases and discrepant results in 78 cases (males and females), of which 37 ( 7.0 per cent.) were diagnosed on selective medium only and 41 ( 7.7 per cent.) on non-selective medium only. Thus, in contrast to the 1969 results, the non-selective medium 'gained' by 0.7 per cent. A closer analysis showed that the ratio $\mathrm{A} / \mathrm{B}$ was reduced from 1.6 to 0.5 in males, but only from 1.8 to 1.6 in females (cf. Table II), presumably because fewer samples from the rectum are received from males than from females. As already mentioned, it is a common feature that the 'gain' of positive results on selective medium is very high in rectal specimens.
Vancomycin is added to the selective medium in order to inhibit Gram-positive organisms. The effect of magnesium ions and EDTA on Escherichia coli and Staphylococcus aureus was examined by Russell (1967), who found that vancomycin lysed E. coli only when the medium was deficient in magnesium ions. The addition of extra magnesium ions to the medium did not prevent vancomycin from inhibiting $S$. aureus. An increased concentration of magnesium ions in the selective medium might also counteract the inhibitory effect of vancomycin on the gonococcal strains sensitive to low concentrations of this drug. However, the addition of 1,10 , or $100 \mu \mathrm{g}$. extra magnesium ions per ml. to the selective medium did not alter the sensitivity of the delicate strains to vancomycin.

\section{Summary}

50,000 specimens of discharge were inoculated on a selective medium containing vancomycin, polymyxin, and nystatin, and on a non-selective medium. Growth of gonococci was obtained from 8,098 specimens, corresponding to 5,500 cases of gonorrhoea. The incidence of gonococcal strains unable to grow on primary inoculation on a selective medium containing $2 \mu \mathrm{g} . / \mathrm{ml}$. vancomycin was estimated to be a minimum of 3.7 per cent.

Altogether 204 cases of gonorrhoea were diagnosed on the non-selective medium only and 354 cases on the selective medium only. Overgrown cultures were rare on the selective medium, the highest incidence observed being 8 per cent. in rectal specimens from males. On the average, 1.7 times as many cases were diagnosed on the selective medium alone as on the non-selective medium alone. The advantage of the selective medium varied with the site and the number of sites; the more sites examined the less was the advantage. The selective medium was especially superior in rectal specimens.

Using a large inoculum, about 40 per cent. of the delicate strains isolated on the non-selective medium only were able to grow on the selective medium. The remaining 125 delicate strains from 120 cases were tested against vancomycin, polymyxin, nystatin, penicillin, streptomycin, and tetracycline. The $\mathrm{IC}_{50}$ value of vancomycin was $\leqslant 2 \mu \mathrm{g} . / \mathrm{ml}$. in 105 of these strains, between 2.4 and $4.8 \mu \mathrm{g} . / \mathrm{ml}$. in fourteen strains, and about $16 \mu \mathrm{g} . / \mathrm{ml}$. in six strains. In 224 strains chosen at random, the range of IC ${ }_{50}$ values of vancomycin was estimated at from $2 \mu \mathrm{g}$. (a few) to $80 \mu \mathrm{g} . / \mathrm{ml}$., with the majority of the strains at $8 \mu \mathrm{g} . / \mathrm{ml}$. In both series, the $\mathrm{IC}_{50}$ values of polymyxin ranged from 50 to $\geqslant 1,300$ i.u. $/ \mathrm{ml}$. All strains were resistant to nystatin. The delicate strains were all sensitive to penicillin, streptomycin, and tetracycline, 
whereas 37 per cent. of the other strains were less sensitive to penicillin ( 55 per cent. of which were resistant to streptomycin) and 8 per cent. were less sensitive to tetracycline.

To prevent loss of strains sensitive to vancomycin, a selective and a non-selective medium should be used together. A check in October, 1971, of 530 cases of gonorrhoea indicated that some loss had occurred since November, 1969. In the intervening period, only about one-third of the specimens had been inoculated on the two media.

The addition of extra magnesium ions to the selective medium did not enhance the resistance of strains sensitive to vancomycin when grown on that medium.

Mrs. R. Glarborg and Mrs. L. Olesen are thanked for valuable technical assistance.

\section{Addendum}

Since the preparation of this manuscript an article dealing with the inhibitory effect of vancomycin on gonococci has come to our attention. Cross, Hoger, Neibaur, Pasternack, and Brady (1971) examined 371 cultures from men. A total of 152 cultures showed growth of gonococci on both selective and non-selective media; an additional thirteen cultures (7.9 per cent.) showed growth of gonococci only on the non-selective medium. The selective medium used contained vancomycin, colistimethate, and nystatin (VCN, Baltimore Biological Laboratory).

\section{References}

Cross, R. C., Hoger, M. B., Neibaur, R., Pasternack, B., and BRADY, F. J. (1971) HSMHA Hlth Rep., 86, 990

Gästrin, B., and Kallings, L. O. (1968) Acta path. microbiol. scand., 74, 362

Heimans, A. L. (1966) Dermatologica (Basel), 133, 319

Holmes, K. K., Counts, G. W., and BeATY, H. N. (1971) Ann. intern. Med., 74, 979

Juhlin, I. (1963) Acta path. microbiol. scand., 58, 51

Møller, V., and ReYN, A. (1965) Bull. Wld Hlth Org., 32, 471

ReYN, A. (1965) Ibid., 32, 449

- (1969) Ibid., 40, 245

, Bentzon, M. W., and Ericsson, H. (1963) Acta path. microbiol. scand., 57, 235

-, Korner, B., and Bentzon, M. W. (1960) Brit. F. vener. Dis., 36, 243

RingerTz, O. (1960) Acta path. microbiol. scand., 48, 105

ROEPSTORFF, S. O., and HAMMERSTRÖM, E. (1966) Ibid., 67, 563

Russell, A. D. (1967) F. appl. Bact., 30, 395

Stuart, R. D., Toshach, S. R., and Patsula, T. M. (1954) Canad. F. publ. Hlth, 45, 73

Thayer, J. D., and Martin, J. E. (1964) Publ. Hlth Rep. (Wash.), 79, 49

- (1966) Ibid., 81, 559

Thomsen, V. FrøuUND (1962) Acta path. microbiol. scand., 54, 107
Wilkinson, A. E. (1965) Brit. F. vener. Dis., 41, 60

Comparaison entre un milieu sélectif et un milieu non sélectif dans le diagnostic de la gonococcie en vue d'établir la sensibilité de Neisseria gonorrhoea à la vancomycine

50.000 spécimens d'écoulements furent ensemencés sur un milieu sélectif contenant vancomycine, polymyxine et nystatine et sur un milieu non sélectif. On obtint une pousse des gonocoques pour 8.098 spécimens, correspondant à 5.500 cas de gonococcie. On estime à un minimum de 3,7 pour cent le nombre des souches de gonocoques incapables de se développer lors du premier ensemencement sur un milieu sélectif contenant $2 \mu \mathrm{g}$. $/ \mathrm{ml}$. de vancomycine.

204 cas de gonococcie furent diagnostiqués uniquement sur le milieu non sélectif et 354 cas uniquement sur le milieu sélectif, les spécimens venant des rectums masculins fournissant la plus haute incidence de développements d'autres germes. En moyenne, on diagnostiqua 1,7 fois plus souvent la maladie sur le milieu sélectif seul que sur le milieu non sélectif seul. L'avantage présenté par le milieu sélectif se montra variable selon le siège du prélèvement et le nombre de ces sièges. Plus grand fut le nombre des lieux de prélèvement, plus faible fut l'avantage. C'est pour les spécimens rectaux que le milieu sélectif fut spécialement supérieur.

Utilisant un inoculum important, à peu près 40 pour cent des souches délicates isolées sur le milieu non sélectif furent capables de se développer sur le milieu sélectif. Les 125 souches délicates restant, provenant de 120 cas, furent testées vis-à-vis de vancomycine, polymyxine, nystatine, pénicilline, streptomycine et tétracycline. La concentration inhibitrice ${ }_{50}$ pour la vancomycine fut $\leq 2 \mu \mathrm{g}$. $/ \mathrm{ml}$. pour 105 de ces souches, entre 2 , 4 et $4,8 \mu \mathrm{g}$. $/ \mathrm{ml}$. pour 14 souches et d'environ $16 \mu \mathrm{g}$. $/ \mathrm{ml}$. pour 6 souches. Pour 224 souches, choisies par randomnisation, le niveau des valeurs de la $\mathrm{CI}_{50}$ pour la vancomycine fut située entre $2 \mu \mathrm{g}$. (un petit nombre) et $80 \mu \mathrm{g}$. $/ \mathrm{ml}$., la majorité de souches se trouvant à $8 \mu \mathrm{g}$. $/ \mathrm{ml}$. Dans les deux séries, les valeurs de la $\mathrm{CI}_{50}$ pour la polymyxine allèrent de 50 à $\leq 1.300 \mathrm{UI} / \mathrm{ml}$. Toutes les souches furent résistante à la nystatine. Toutes les souches délicates furent sensibles à pénicilline, streptomycine et tétracycline alors que 37 pour cent des autres souches furent moins sensibles à la pénicilline ( 55 pour cent d'entre elles étaient résistantes à la streptomycine) et 8 pour cent furent moins sensibles à la tétracycline.

Pour éviter la perte de souches sensibles à la vancomycine, il faut utiliser conjointement un milieu sélectif et un milieu non sélectif. Un pointage sur 530 cas de gonococcie, effectué en Octobre 1971, a montré que depuis Novembre 1969 un certain nombre de souches avaient été perdues. Entre ces deux dates, environ un tiers seulement des spécimens avaient été inoculés sur les deux milieux.

Une addition au milieu sélectif d'ions magnésium supplémentaires n'a pas augmenté la résistance des souches sensibles à la vancomycine lorsqu'elles étaient cultivées sur un tel milieu. 